\title{
An overview of the role of D-dimer in COVID-19: elevated D-dimer level is associated with disease severity
}

\author{
Moran Wang ${ }^{1}$, Shengling $\mathrm{Ma}^{1}$, Shanshan $\mathrm{Luo}^{1}$, and $\mathrm{Yu} \mathrm{Hu}{ }^{1}$ \\ ${ }^{1}$ Affiliation not available
}

June 22, 2020

\begin{abstract}
The great number of patients presenting to health centers or hospitals during the outbreak of coronavirus disease 2019 (COVID19) overwhelms the need for critical care support. Early and effective predictors for clinical outcomes are urgently needed for risk stratification. Critically ill patients often develop coagulation disorders, in particular hypercoagulation. Elevated D-dimer is a prominent indicator for the initial coagulopathy of COVID-19. To estimate whether D-dimer is associated with the severity of COVID-19, we performed the analysis of D-dimer abnormalities in patients with COVID-19. The data demonstrated that D-dimer levels were significantly higher in deceased patients than in survivors (weighted mean difference(WMD): 3.70mg/L, $95 \%$ confidence interval(CI):1.41-5.98mg/L), and the levels in severe patients were also higher than those in mild cases (WMD: $0.39 \mathrm{mg} / \mathrm{L}, 95 \% \mathrm{CI}: 0.22-0.55 \mathrm{mg} / \mathrm{L})$. Therefore, we conclude that elevated D-dimer level is related to the severity and poor prognosis of patients with COVID-19.
\end{abstract}

An overview of the role of D-dimer in COVID-19: elevated D-dimer level is associated withdisease severity

Short title: An overview of the role of D-dimer in COVID-19

Moran Wang ${ }^{1}$, Shengling $\mathrm{Ma}^{1}$, Shanshan $\mathrm{Luo}^{1 \#}$, Yu Hu${ }^{1 \#}$

${ }^{1}$ Institute of Hematology, Union Hospital, Tongji Medical College, Huazhong University of Science and Technology, 1277 Jiefang Road, Wuhan 430022, China.

\# shared corresponding authors

Yu Hu: Email: dr_huyu@126.com; Tel.: +86-27-85726007; Fax: +86-27-85726387.

Shanshan Luo: Email: shsh689@126.com; Tel.: +86-27-85726007; Fax: +86-27-85726387.

Word count

Abstract:145

Text: 1291

Figure count: 2

Table count: 2

Reference count: 39 


\begin{abstract}
The great number of patients presenting to health centers or hospitals during the outbreak of coronavirus disease 2019 (COVID-19) overwhelms the need for critical care support. Early and effective predictors for clinical outcomes are urgently needed for risk stratification. Critically ill patients often develop coagulation disorders, in particular hypercoagulation. Elevated D-dimer is a prominent indicator for the initial coagulopathy of COVID-19. To estimate whether D-dimer is associated with the severity of COVID-19, we performed the analysis of D-dimer abnormalities in patients with COVID-19. The data demonstrated that D-dimer levels were significantly higher in deceased patients than in survivors (weighted mean difference(WMD): $3.70 \mathrm{mg} / \mathrm{L}, 95 \%$ confidence interval(CI):1.41-5.98mg/L), and the levels in severe patients were also higher than those in mild cases (WMD: $0.39 \mathrm{mg} / \mathrm{L}, 95 \%$ CI: $0.22-0.55 \mathrm{mg} / \mathrm{L}$ ). Therefore, we conclude that elevated D-dimer level is related to the severity and poor prognosis of patients with COVID-19. (145 words)
\end{abstract}

Key words : COVID-19, D-dimer, Coagulopathy, Severity

\title{
Introduction
}

Since December 2019, the outbreak of COVID-19 put the health authorities of the whole world on high alert. According to the latest statistics released by the World Health Organization on June 17,2020, severe acute respiratory syndrome coronavirus 2 (SARS-CoV-2 ) has already infected over 8 million people from over 200 countries worldwide, causing more than 400,000 deaths("World Health Organization.,"). SARS-CoV-2 can cause serious diseases, including acute respiratory distress and occasionally associated with multiple organ dysfunction failure(Mattiuzzi \& Lippi, 2020). During the course of SARS-CoV-2 infection, critical patients developed uncorrectable coagulation dysfunction. Existence of disseminated intravascular coagulation is common in deaths with COVID-19(Tang, Li, Wang, \& Sun, 2020). The initial coagulopathy of COVID-19 is accompanied with prominent elevation of D-dimer and fibrin/fibrinogen degradation products(Connors \& Levy, 2020). Also, markedly elevated D-dimer levels were reported in the deceased patients(Tang et al., 2020), suggesting that elevated D-dimer is closely related to poor prognosis. In this review, we studied the roles of D-dimer in infections, then performed the analysis of D-dimer abnormalities in patients with COVID-19 to better estimate the role of D-dimer in predicting the prognosis of SARS-CoV-2 infected patients.

\section{General roles of D-dimer in infections}

On-admission, D-dimer level is usually used to predict disease severity and mortality in endocarditis and severe patients without obvious disseminated intravascular coagulation(Shorr, Trotta, Alkins, Hanzel, \& Diehl, 1999; Turak et al., 2014). A cohort study by Michael et al. found that patients with bacteremia had a higher risk of in-hospital mortality on the first day of positive blood culture with elevated D-dimer levels(Schwameis et al., 2015). Elevated D-dimer levels have also been reported in patients with acute lung injury and acute respiratory distress syndrome(Wenzel et al., 2002). Lee et al. had reported the clinical and laboratory features of 138 cases of suspected SARS in Hong Kong, which was striking that $45 \%$ of the patients had elevated D-dimer levels(Lee et al., 2003). Notably, most SARS-CoV-2 infected patients with systemic inflammatory response syndrome are associated with significantly elevated D-dimer, especially in critically ill patients (Mehta et al., 2020). In a study of 1099 patients with COVID-19 from over 550 hospitals in China, a D-dimer [?]0.5 mg/L was noted in 260/560 (46.4\%) patients, and about $60 \%$ of severe patients have elevated D-dimer(Guan et al., 2020). Furthermore, markedly elevated D-dimer levels were also observed in the deceased patients with COVID-19 (Tang et al., 2020). 


\section{D-dimer is associated with severity of COVID-19}

Given the important roles of D-dimer in infections, we speculated that D-dimer can be used to track the severity of COVID-19. To address this hypothesis, we reviewed studies that reported information on the difference of D-dimer values from COVID-19 patients with different backgrounds (i.e., those who need mechanical ventilation, or intensive care unit (ICU) admission, or those who died) from December 1, 2019 to June 10, 2020, without language restriction. Based on these literatures, we performed a pooled analysis with calculation of WMD and 95\% CI of D-dimer values between deceased patients and survivors with COVID19(Du et al., 2020; Fogarty et al., 2020; Tang et al., 2020; Wu et al., 2020; Yan et al., 2020; J. Zhang et al., 2020; Zhou et al., 2020)(subgroup 1, consisting 7 studies, characteristics presented in Table 1 ), and between COVID-19 patients with or without severe disease(G. Chen et al., 2020; Q. Chen et al., 2020; Huang, Wang, \& Li, 2020; Ji et al., 2020; M. Liu et al., 2020; Liu, Liao, Wan, Xiang, \& Zhang, 2020; Wei et al., 2020; Wu et al., 2020; Xie et al., 2020; J. J. Zhang et al., 2020; Zheng et al., 2020; Zhu et al., 2020; Zou et al., 2020)(subgroup 2, consisting 13 studies, characteristics presented in Table 2 ), using R software Version 3.6.3. The severe group met any of the following criteria: (a) Increased breathing rate ([?]30 beats/min), (b) resting-state oxygen saturation [?]93\%, (c) arterial partial pressure of oxygen/oxygen concentration[?]300mm $\mathrm{Hg}$ ("Diagnosis and Treatment of Pneumonia Caused by SARS-CoV-2(version 7). National Health Commission of the People's Republic of China,"), or (d) respiratory failure, mechanical ventilation, shock, or other functional organ failure requiring ICU monitoring and treatment. Mean and standard deviation were extrapolated from sample size, median, and interquartile range according to Wan et al.(Wan, Wang, Liu, \& Tong, 2014) and Luo et al.(Luo, Wan, Liu, \& Tong, 2018).

The WMD of subgroup 1 (597 patients in total, 32\% were deceased patients) was summarized inFigure 1, showing that D-dimer levels were significantly higher in deceased patients than those in survivors with COVID-19 (WMD: $3.70 \mathrm{mg} / \mathrm{L}, 95 \%$ CI: $1.41-5.98 \mathrm{mg} / \mathrm{L}$ ), the heterogeneity of subgroup 1 was relatively high (I-square $\left.\left(\mathrm{I}^{2}\right), 86 \% ; \mathrm{p}<0.01\right)$. The WMD of subgroup 2 (1172 patients in total, $35 \%$ with severe disease) was summarized in Figure 2, showing that D-dimer levels in severe patients were higher than those in the mild cases (WMD: $0.39 \mathrm{mg} / \mathrm{L}, 95 \%$ CI: $0.22-0.55 \mathrm{mg} / \mathrm{L}$ ), while the heterogeneity of subgroup 2 was relatively high $\left(\mathrm{I}^{2}, 84 \% ; \mathrm{p}<0.01\right)$.

\section{Vigilance against elevated D-dimer levels}

D-dimer level at the time of hospital admission is a risk predictor for the development of acute respiratory distress syndrome, ICU admission and death(Huang et al., 2020; Wu et al., 2020). An observational study in COVID-19 patients with elevated D-dimer levels showed that the 28-day mortality of heparin treated patients was lower than those from non-treated ones(Zhou et al., 2020). In a trial consisting of 31 patients with COVID-19, dipyridamole supplementation was associated with significantly decreased concentration of D-dimers, increased lymphocytes and platelet recovery in the circulation, suggesting markedly improved clinical outcomes(X. Liu et al., 2020). Similarly, Escher et al. also reported that the "decrease" of D-dimer levels (from $6.26 \mathrm{mg} / \mathrm{L}$ to $1.94 \mathrm{mg} / \mathrm{L}$ ) in a patient after escalating the treatment dose of anticoagulation reflected clinical improvement(Escher, Breakey, \& Lammle, 2020).

High concentration of D-dimer indicates a hypercoagulable state in patients with COVID-19, which is closely related to thromboembolism(Kline, Garrett, Sarmiento, Strachan, \& Courtney, 2020). Cui et al. used a D-dimer cut-off of $1.5 \mu \mathrm{g} / \mathrm{mL}$ for predicting venous thromboembolism and demonstrating sensitivity of $85.0 \%$, specificity of $88.5 \%$ and negative predictive value of $94.7 \%$ (Cui, Chen, Li, Liu, \& Wang, 2020). The Swiss Society of Hematology proposed that for patients in ICU with a large increase of D-dimer, severe inflammation, or signs of hepatic, or renal dysfunction or imminent respiratory failure, intermediate or therapeutic dosing of low molecular weight heparin or unfractionated heparin should be applied based on the bleeding risk(Casini et al., 2020). As for venous thromboembolism prophylaxis, many centers have increased the dose of anticoagulation as a risk-adapted strategy based on the levels of D-dimer, fibrinogen, ICU location, or other factors associated with increased risk(Connors \& Levy, 2020). 


\section{Conclusion}

In this work, we performed a pooled analysis for D-dimer abnormalities that occurred in association with COVID-19 based on published data, found that D-dimer levels were considerably higher in severe or deceased patients than in mild ones or survivors with COVID-19, suggesting that elevated D-dimer level is closely related to the severity and poor prognosis of patients. Thereby, we conclude that D-dimer can be used as the early and effective predictor for the judgment of the disease severity, which is of great importance in clinical use. However, larger prospective studies are needed in the future to classify the mechanism how SARS-CoV-2 caused hypercoagulation, in particular elevated D-dimer levels.

Our review has several limitations. First, most of the studies reported the change of D-dimer levels are observational studies, and there are few longitudinal comparison studies. In addition, only one literature which we analyzed is not derived from studies of Chinese patients. Since race and ethnicity have major effects upon thrombotic risk (Liao et al., 2014; White \& Keenan, 2009), data from other countries need to be updated.

\section{Notes}

Ethical Statement: No ethical approval was required as this is a review article with no original research data.

Data availability statement: The data that support the findings of this study are available on request from the corresponding author.

Acknowledgement: The authors would like to thank all the study participants.

Author contributions: Yu Hu and Shanshan Luo designed the study; Moran Wang and Shengling Ma collected the data, and wrote the paper; $\mathrm{Yu} \mathrm{Hu}$ and Shanshan Luo analyzed the data and modified the grammatical structure of the article; all authors reviewed the paper and approved the final manuscript.

Potential conflicts of interest:The authors declare no conflicts of interest.

Funding: This work was supported by the National Natural Science Foundation of China (grant number 81601747).

\section{References}

Casini, A., Alberio, L., Angelillo-Scherrer, A., Fontana, P., Gerber, B., Graf, L., . . . Asmis, L. (2020). Thromboprophylaxis and laboratory monitoring for in-hospital patients with COVID-19 - a Swiss consensus statement by the Working Party Hemostasis. Swiss Med Wkly, 150, w20247. doi:10.4414/smw.2020.20247

Chen, G., Wu, D., Guo, W., Cao, Y., Huang, D., Wang, H., . . . Ning, Q. (2020). Clinical and immunological features of severe and moderate coronavirus disease 2019. J Clin Invest, 130 (5), 2620-2629. doi:10.1172/jci137244

Chen, Q., Zheng, Z., Zhang, C., Zhang, X., Wu, H., Wang, J., . . . Zheng, C. (2020). Clinical characteristics of 145 patients with corona virus disease 2019 (COVID-19) in Taizhou, Zhejiang, China.Infection . doi:10.1007/s15010-020-01432-5

Connors, J. M., \& Levy, J. H. (2020). COVID-19 and its implications for thrombosis and anticoagulation. Blood . doi:10.1182/blood.2020006000

Cui, S., Chen, S., Li, X., Liu, S., \& Wang, F. (2020). Prevalence of venous thromboembolism in patients with severe novel coronavirus pneumonia. J Thromb Haemost . doi:10.1111/jth.14830

Diagnosis and Treatment of Pneumonia Caused by SARS-CoV-2(version 7).Na-

tional Health Commission of the People's Republic of China. Retrieved fromhttp://www.nhc.gov.cn/xcs/zhengcwj/202003/46c9294a7dfe4cef80dc7f5912eb1989/files/ce3e6945832a438eaae415350a8c 
Du, R. H., Liang, L. R., Yang, C. Q., Wang, W., Cao, T. Z., Li, M., . . . Shi, H. Z. (2020). Predictors of Mortality for Patients with COVID-19 Pneumonia Caused by SARS-CoV-2: A Prospective Cohort Study. Eur Respir J . doi:10.1183/13993003.00524-2020

Escher, R., Breakey, N., \& Lammle, B. (2020). Severe COVID-19 infection associated with endothelial activation. Thromb Res, 190 , 62. doi:10.1016/j.thromres.2020.04.014

Fogarty, H., Townsend, L., Ni Cheallaigh, C., Bergin, C., Martin-Loeches, I., Browne, P., . . . JS, O. D. (2020). COVID-19 Coagulopathy in Caucasian patients. Br J Haematol . doi:10.1111/bjh.16749

Guan, W.-J., Ni, Z.-Y., Hu, Y., Liang, W.-H., Ou, C.-Q., He, J.-X., . . . China Medical Treatment Expert Group for, C. (2020). Clinical Characteristics of Coronavirus Disease 2019 in China. The New England journal of medicine. Retrieved from < Go to ISI>://MEDLINE:32109013. doi:10.1056/NEJMoa2002032

Huang, C., Wang, Y., \& Li, X. (2020). Clinical features of patients infected with 2019 novel coronavirus in Wuhan, China (vol 395, pg 497, 2020). Lancet, 395 (10223), 496-496. Retrieved from <Go to ISI > :/WOS:000514576900031. doi:10.1016/s0140-6736(20)30252-x

Ji, D., Zhang, D., Xu, J., Chen, Z., Yang, T., Zhao, P., . . . Qin, E. (2020). Prediction for Progression Risk in Patients with COVID-19 Pneumonia: the CALL Score. Clin Infect Dis . doi:10.1093/cid/ciaa414

Kline, J. A., Garrett, J. S., Sarmiento, E. J., Strachan, C. C., \& Courtney, D. M. (2020). Over-Testing for Suspected Pulmonary Embolism in American Emergency Departments: The Continuing Epidemic. Circ Cardiovasc Qual Outcomes, 13 (1), e005753. doi:10.1161/circoutcomes.119.005753

Lee, N., Hui, D., Wu, A., Chan, P., Cameron, P., Joynt, G. M., . . . Sung, J. J. (2003). A major outbreak of severe acute respiratory syndrome in Hong Kong. $N$ Engl J Med, 348 (20), 1986-1994. doi:10.1056/NEJMoa030685

Liao, S., Woulfe, T., Hyder, S., Merriman, E., Simpson, D., \& Chunilal, S. (2014). Incidence of venous thromboembolism in different ethnic groups: a regional direct comparison study. J Thromb Haemost, 12 (2), 214-219. doi:10.1111/jth.12464

Liu, M., He, P., Liu, H. G., Wang, X. J., Li, F. J., Chen, S., . . . Li, C. H. (2020). [Clinical characteristics of 30 medical workers infected with new coronavirus pneumonia]. Zhonghua Jie He He Hu Xi Za Zhi, 43 (3), 209-214. doi:10.3760/cma.j.issn.1001-0939.2020.03.014

Liu, X., Li, Z., Liu, S., Sun, J., Chen, Z., Jiang, M., . . . Luo, H. B. (2020). Potential therapeutic effects of dipyridamole in the severely ill patients with COVID-19. Acta Pharm Sin B . doi:10.1016/j.apsb.2020.04.008

Liu, Y., Liao, W., Wan, L., Xiang, T., \& Zhang, W. (2020). Correlation Between Relative Nasopharyngeal Virus RNA Load and Lymphocyte Count Disease Severity in Patients with COVID-19. Viral Immunol . doi:10.1089/vim.2020.0062

Luo, D., Wan, X., Liu, J., \& Tong, T. (2018). Optimally estimating the sample mean from the sample size, median, mid-range, and/or mid-quartile range. Stat Methods Med Res, 27 (6), 1785-1805. doi:10.1177/0962280216669183

Mattiuzzi, C., \& Lippi, G. (2020). Which lessons shall we learn from the 2019 novel coronavirus outbreak? Ann Transl Med, 8 (3), 48. doi:10.21037/atm.2020.02.06

Mehta, P., McAuley, D. F., Brown, M., Sanchez, E., Tattersall, R. S., \& Manson, J. J. (2020). COVID-19: consider cytokine storm syndromes and immunosuppression. Lancet, 395 (10229), 1033-1034. doi:10.1016/s0140-6736(20)30628-0

Schwameis, M., Steiner, M. M., Schoergenhofer, C., Lagler, H., Buchtele, N., Jilma-Stohlawetz, P., . . - Jilma, B. (2015). D-dimer and histamine in early stage bacteremia: A prospective controlled cohort study.Eur J Intern Med, 26 (10), 782-786. doi:10.1016/j.ejim.2015.10.024 
Shorr, A. F., Trotta, R. F., Alkins, S. A., Hanzel, G. S., \& Diehl, L. F. (1999). D-dimer assay predicts mortality in critically ill patients without disseminated intravascular coagulation or venous thromboembolic disease. Intensive Care Med, 25 (2), 207-210. doi:10.1007/s001340050817

Tang, N., Li, D., Wang, X., \& Sun, Z. (2020). Abnormal coagulation parameters are associated with poor prognosis in patients with novel coronavirus pneumonia. J Thromb Haemost . doi:10.1111/jth.14768

Turak, O., Canpolat, U., Özcan, F., Yayla, C., Mendi, M. A., Öksüz, F., . . Gölbaşı, Z. (2014). D-dimer level predicts in-hospital mortality in patients with infective endocarditis: A prospective single-centre study. Thromb Res, 134 (3), 587-592. doi:10.1016/j.thromres.2014.06.015

Wan, X., Wang, W., Liu, J., \& Tong, T. (2014). Estimating the sample mean and standard deviation from the sample size, median, range and/or interquartile range. BMC Med Res Methodol, 14, 135. doi:10.1186/1471$2288-14-135$

Wei, Y. Y., Wang, R. R., Zhang, D. W., Tu, Y. H., Chen, C. S., Ji, S., . . . Fei, G. H. (2020). Risk factors for severe COVID-19: Evidence from 167 hospitalized patients in Anhui, China. J Infect . doi:10.1016/j.jinf.2020.04.010

Wenzel, C., Kofler, J., Locker, G. J., Laczika, K., Quehenberger, P., Frass, M., \& Knobl, P. (2002). Endothelial cell activation and blood coagulation in critically ill patients with lung injury. Wien Klin Wochenschr, 114 (19-20), 853-858.

White, R. H., \& Keenan, C. R. (2009). Effects of race and ethnicity on the incidence of venous thromboembolism. Thromb Res, 123 Suppl 4, S11-17. doi:10.1016/s0049-3848(09)70136-7

World Health Organization. Coronavirus disease 2019 (COVID-19) Situation Report-149. June 17,2020. Retrieved fromhttps://www.who.int/docs/default-source/coronaviruse/situation-reports/20200617-covid-19sitrep-149.pdf?sfursn=3b3137b0_4

Wu, C., Chen, X., Cai, Y., Xia, J., Zhou, X., Xu, S., . . . Song, Y. (2020). Risk Factors Associated With Acute Respiratory Distress Syndrome and Death in Patients With Coronavirus Disease 2019 Pneumonia in Wuhan, China. JAMA Intern Med . doi:10.1001/jamainternmed.2020.0994

Xie, J., Ding, C., Li, J., Wang, Y., Guo, H., Lu, Z., . . . He, H. (2020). Characteristics of Patients with Coronavirus Disease (COVID-19) Confirmed using an IgM-IgG Antibody Test. J Med Virol . doi:10.1002/jmv.25930

Yan, Y., Yang, Y., Wang, F., Ren, H., Zhang, S., Shi, X., . . . Dong, K. (2020). Clinical characteristics and outcomes of patients with severe covid-19 with diabetes. BMJ Open Diabetes Res Care, 8 (1). doi:10.1136/bmjdrc-2020-001343

Zhang, J., Liu, P., Wang, M., Wang, J., Chen, J., Yuan, W., . . . Ma, J. (2020). The clinical data from 19 critically ill patients with coronavirus disease 2019: a single-centered, retrospective, observational study. $Z$ Gesundh Wiss , 1-4. doi:10.1007/s10389-020-01291-2

Zhang, J. J., Dong, X., Cao, Y. Y., Yuan, Y. D., Yang, Y. B., Yan, Y. Q., . . . Gao, Y. D. (2020). Clinical characteristics of 140 patients infected with SARS-CoV-2 in Wuhan, China. Allergy . doi:10.1111/all.14238

Zheng, Y., Xu, H., Yang, M., Zeng, Y., Chen, H., Liu, R., . . . Wang, D. (2020). Epidemiological characteristics and clinical features of 32 critical and 67 noncritical cases of COVID-19 in Chengdu. J Clin Virol, 127 , 104366. doi:10.1016/j.jcv.2020.104366

Zhou, F., Yu, T., Du, R., Fan, G., Liu, Y., Liu, Z., . . . Cao, B. (2020). Clinical course and risk factors for mortality of adult inpatients with COVID-19 in Wuhan, China: a retrospective cohort study.Lancet, 395 (10229), 1054-1062. doi:10.1016/s0140-6736(20)30566-3

Zhu, Z., Cai, T., Fan, L., Lou, K., Hua, X., Huang, Z., \& Gao, G. (2020). Clinical value of immune-inflammatory parameters to assess the severity of coronavirus disease 2019. Int J Infect Dis . 
doi:10.1016/j.ijid.2020.04.041

Zou, Y., Guo, H., Zhang, Y., Zhang, Z., Liu, Y., Wang, J., . . . Qian, Z. (2020). Analysis of coagulation parameters in patients with COVID-19 in Shanghai, China. Biosci Trends . doi:10.5582/bst.2020.03086

Table 1. D-dimer values between deceased patients and survivors with coronavirus disease 2019.

\begin{tabular}{|c|c|c|c|c|c|c|c|}
\hline Study & Country & All patients & $\begin{array}{l}\text { Deceased } \\
\text { patients }\end{array}$ & Survivors & $\begin{array}{l}\text { D-dimer } \\
(\mathrm{mg} / \mathrm{L})\end{array}$ & $\begin{array}{l}\text { D-dimer } \\
(\mathrm{mg} / \mathrm{L})\end{array}$ & $\begin{array}{l}\text { D-dimer } \\
(\mathrm{mg} / \mathrm{L})\end{array}$ \\
\hline & & & & & $\begin{array}{l}\text { Deceased } \\
\text { patients }\end{array}$ & Survivors & $\mathrm{P}$ values \\
\hline $\begin{array}{l}\text { Du.R(Du } \\
\text { et al., } \\
2020)\end{array}$ & China & 179 & 21 & 158 & $\begin{array}{l}1.1(0.4- \\
10.5)\end{array}$ & $\begin{array}{l}0.5(0.3- \\
1.2)\end{array}$ & 0.011 \\
\hline \multicolumn{2}{|c|}{$\begin{array}{l}\text { Fogarty.H(Fogaitryland } \\
\text { et al., 2020) }\end{array}$} & 83 & 33 & 50 & $\begin{array}{l}1.003(0.537- \\
1.782)\end{array}$ & $\begin{array}{l}0.804 \\
(0.513-1.29)\end{array}$ & 0.018 \\
\hline $\begin{array}{l}\text { Tang.N(Tang } \\
\text { et al., 2020) }\end{array}$ & China & 183 & 21 & 162 & $\begin{array}{l}2.12 \\
(0.77-5.27)\end{array}$ & $\begin{array}{l}0.61 \\
(0.35-1.29)\end{array}$ & $<0.001$ \\
\hline $\begin{array}{l}\text { Wu.C(Wu et } \\
\text { al., 2020) }\end{array}$ & China & 84 & 44 & 40 & $\begin{array}{l}3.95 \\
(1.15-10.96)\end{array}$ & $\begin{array}{l}0.49 \\
(0.31-1.18)\end{array}$ & 0.001 \\
\hline $\begin{array}{l}\text { Yan.YL(Yan } \\
\text { et al., 2020) }\end{array}$ & China & 48 & 9 & 39 & $\begin{array}{l}4.95 \\
(1.80-21)\end{array}$ & $\begin{array}{l}0.41 \\
(0.26-0.89)\end{array}$ & $<0.001$ \\
\hline $\begin{array}{l}\text { Zhang.JP(J. } \\
\text { Zhang et al., } \\
\text { 2020) }\end{array}$ & China & 19 & 8 & 11 & $2.15(1.4-9.2)$ & $\begin{array}{l}0.48 \\
(0.42-0.97)\end{array}$ & $<0.05$ \\
\hline $\begin{array}{l}\text { Zhou.F(Zhou } \\
\text { et al., } \\
2020)\end{array}$ & China & 191 & 54 & 137 & $\begin{array}{l}5.2 \\
(1.5-21.1)\end{array}$ & $\begin{array}{l}0.6(0.3- \\
1.0)\end{array}$ & $<0.0001$ \\
\hline
\end{tabular}

Data are median (interquartile range); $\mathrm{P}$ values comparing deceased patients and survivors with coronavirus disease 2019 are from $\chi^{2}$ test, Fisher's exact test, or Mann-Whitney U test.

\begin{tabular}{|c|c|c|c|c|c|c|c|}
\hline Study & Country & All patients & Severe & Non- severe & $\begin{array}{l}\text { D-dimer } \\
(\mathrm{mg} / \mathrm{L})\end{array}$ & $\begin{array}{l}\text { D-dimer } \\
(\mathrm{mg} / \mathrm{L})\end{array}$ & $\begin{array}{l}\text { D-dimer } \\
(\mathrm{mg} / \mathrm{L})\end{array}$ \\
\hline & & & & & Severe & $\begin{array}{l}\text { Non- } \\
\text { severe }\end{array}$ & $\mathrm{P}$ values \\
\hline $\begin{array}{l}\text { Chen.G(G. } \\
\text { Chen et } \\
\text { al., 2020) }\end{array}$ & China & 21 & 11 & 10 & $8.2 \pm 9.0$ & $0.4 \pm 0.3$ & 0.025 \\
\hline $\begin{array}{l}\text { Chen.QQ(Q. } \\
\text { Chen et al., } \\
2020)\end{array}$ & China & 145 & 43 & 102 & $\begin{array}{l}0.32 \\
(0.21-0.49)\end{array}$ & $\begin{array}{l}0.24 \\
(0.16-0.39)\end{array}$ & 0.110 \\
\hline $\begin{array}{l}\text { Huang.C(Huan } \\
\text { et al., } \\
2020)\end{array}$ & gChina & 41 & 13 & 28 & $\begin{array}{l}2.4(0.6- \\
14.4)\end{array}$ & $\begin{array}{l}0.5 \\
(0.3-0.8)\end{array}$ & 0.004 \\
\hline $\begin{array}{l}\text { Ji.D(Ji et } \\
\text { al., 2020) }\end{array}$ & China & 208 & 40 & 168 & $\begin{array}{l}0.48 \\
(0.31-0.75)\end{array}$ & $\begin{array}{l}0.24 \\
(0.19-0.43)\end{array}$ & $<0.001$ \\
\hline
\end{tabular}




\begin{tabular}{|c|c|c|c|c|c|c|c|}
\hline Study & Country & All patients & Severe & Non- severe & $\begin{array}{l}\text { D-dimer } \\
(\mathrm{mg} / \mathrm{L})\end{array}$ & $\begin{array}{l}\text { D-dimer } \\
(\mathrm{mg} / \mathrm{L})\end{array}$ & $\begin{array}{l}\text { D-dimer } \\
(\mathrm{mg} / \mathrm{L})\end{array}$ \\
\hline $\begin{array}{l}\text { Liu.M(M. } \\
\text { Liu et al., } \\
2020)\end{array}$ & China & 30 & 4 & 26 & $1.54 \pm 1.22$ & $0.26 \pm 0.08$ & $<0.001$ \\
\hline $\begin{array}{l}\text { Liu.Y(Y. } \\
\text { Liu et al., } \\
2020)\end{array}$ & China & 76 & 30 & 46 & $1(0.33-2.42)$ & $\begin{array}{l}0.26 \\
(0.16-0.45)\end{array}$ & $<0.001$ \\
\hline $\begin{array}{l}\text { Wei.YY(Wei } \\
\text { et al., 2020) }\end{array}$ & China & 167 & 30 & 137 & $\begin{array}{l}0.35 \\
(0.23-0.58)\end{array}$ & $\begin{array}{l}0.26 \\
(0.19-0.51)\end{array}$ & 0.106 \\
\hline $\begin{array}{l}\text { Wu.C(Wu et } \\
\text { al., 2020) }\end{array}$ & China & 201 & 84 & 117 & $\begin{array}{l}1.16 \\
(0.46-5.37)\end{array}$ & $\begin{array}{l}0.52(0.33- \\
0.93)\end{array}$ & $<0.001$ \\
\hline $\begin{array}{l}\text { Xie JJ(Xie } \\
\text { et al., 2020) }\end{array}$ & China & 56 & 34 & 22 & $\begin{array}{l}0.59 \\
(0.22-1.0)\end{array}$ & $\begin{array}{l}0.34 \\
(0.22-0.54)\end{array}$ & 0.180 \\
\hline $\begin{array}{l}\text { Zhang.JJ(J. } \\
\text { J. Zhang } \\
\text { et al., } \\
2020)\end{array}$ & China & 138 & 56 & 82 & $\begin{array}{l}0.4 \\
(0.2-2.4)\end{array}$ & $\begin{array}{l}0.2 \\
(0.1-0.3)\end{array}$ & $<0.001$ \\
\hline $\begin{array}{l}\text { Zheng.Y(Zheng } \\
\text { et al., } \\
2020)\end{array}$ & China & 94 & 32 & 62 & $2.65 \pm 3.93$ & $0.78 \pm 0.76$ & 0.000 \\
\hline $\begin{array}{l}\text { Zhu.Z(Zhu } \\
\text { et al., 2020) }\end{array}$ & China & 105 & 10 & 95 & $\begin{array}{l}0.161(0.074- \\
0.283)\end{array}$ & $\begin{array}{l}0.1(0.082- \\
0.158)\end{array}$ & 0.195 \\
\hline $\begin{array}{l}\text { Zou.Y(Zou } \\
\text { et al., 2020) }\end{array}$ & China & 303 & 26 & 277 & $\begin{array}{l}1.04 \\
(0.73-1.72)\end{array}$ & $\begin{array}{l}0.43 \\
(0.31-0.77)\end{array}$ & $<0.001$ \\
\hline
\end{tabular}

Table 2. D-dimer values between severe and non-severe patients with coronavirus disease 2019.

Data are median (interquartile range) and mean \pm standard deviation; $\mathrm{P}$ values comparing severe and nonsevere patients with coronavirus disease 2019 are from $\chi^{2}$ test, Fisher's exact test, or Mann-Whitney U test.

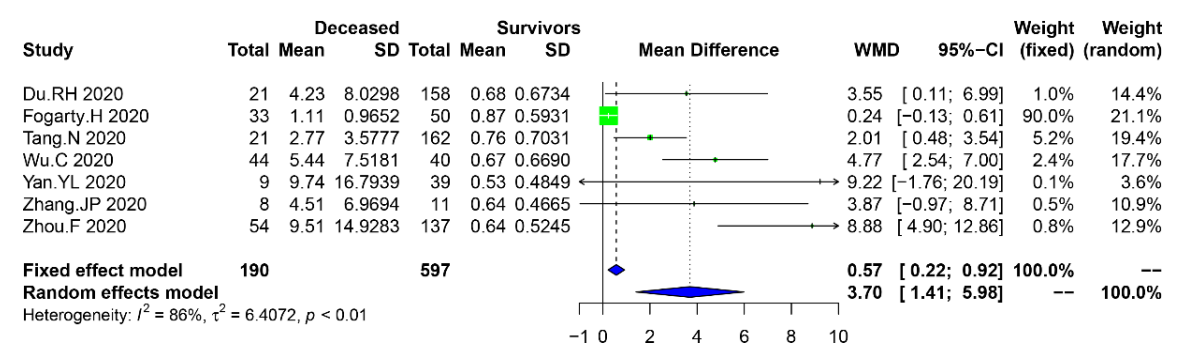

Figure 1. Weighted mean difference and $95 \%$ confidence interval of D-dimer values between deceased patients and survivors with coronavirus disease 2019. 


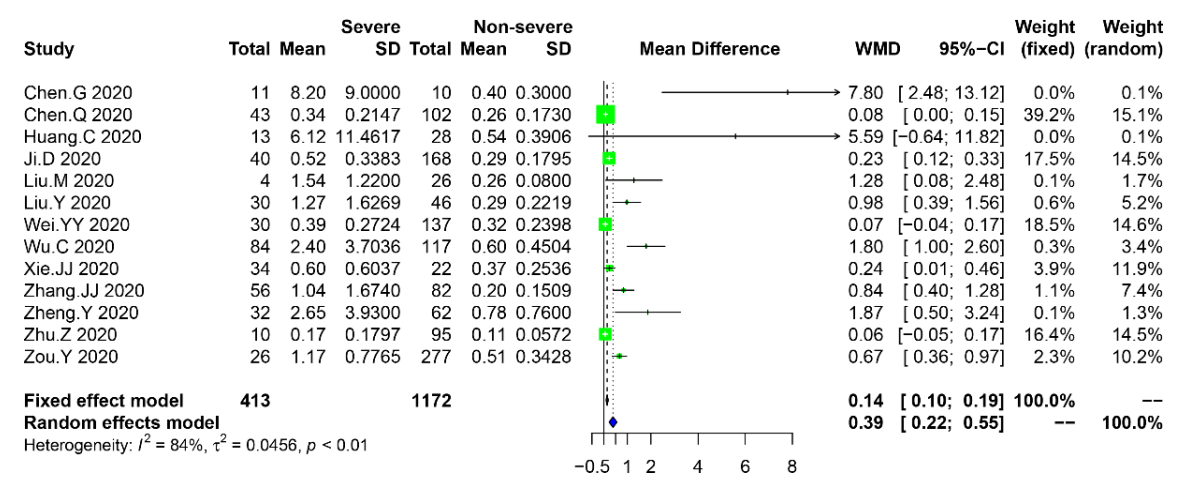

Figure 2. Weighted mean difference and $95 \%$ confidence interval of D-dimer values between severe and non-severe patients with coronavirus disease 2019. 